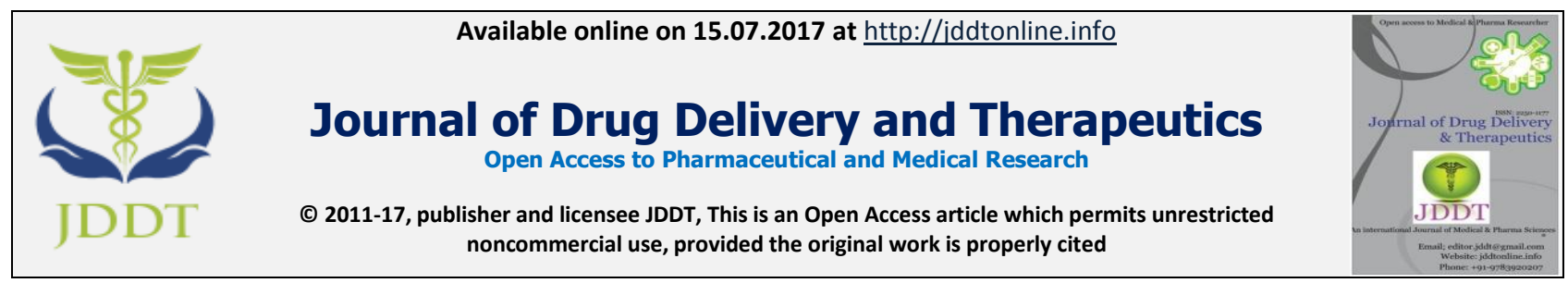

Open $\odot_{\text {Access }}$

Review Article

\title{
FUTURE PERSPECTIVES OF DROSERA MAGNIFICA: THE FIRST EVER PLANT DISCOVERED ON THE SOCIAL MEDIA
}

\author{
Preet Amol Singh ${ }^{1}$, Neha Bajwa ${ }^{2 *}$ \\ ${ }^{1}$ College of Pharmacy, Pt. B.D. Sharma University of Health Sciences (P.G.I.M.S), Rohtak-124001, Haryana, India \\ ${ }^{2}$ GVM College of Pharmacy, Sonepat, Haryana, India
}

\section{ABSTRACT}

A long cycle of adaptation is going on in the ecosystem either it is a human being who adapted or a plant. Recently carnivorous plants have taken the stage of adaptation. By not getting photosynthesis and nitrogen from the environment non carnivorous plants have adapted to carnivorous species. Researchers have discovered thousands of new species of carnivorous plants. Recently the social network photographs have revealed the third largest species of Droserea family that is Droserea magnifica. In this article, we have discussed Droserea magnifica, its discovery, habitat and its future prospects in relation to its phytochemistry and pharmacology.

Keywords: Carnivorous, Droseraceae, Drosera magnifica, Phytochemistry, Pharmacology.

Article Info: Received 28 May, 2017; Review Completed 13 July, 2017; Accepted 14 July, 2017; Available online 15 July, 2017

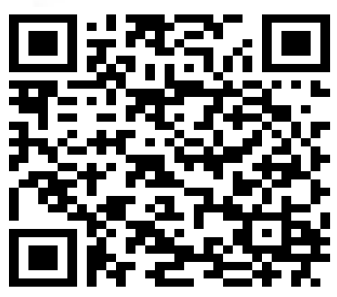

Cite this article as:

Singh PA, Bajwa N, Future perspectives of drosera magnifica: the first ever plant discovered on the social media, Journal of Drug Delivery and Therapeutics. 2017; 7(4):12-19

DOI: http://dx.doi.org/10.22270/jddt.v7i4.1474

*Address for Correspondence

Neha Bajwa, GVM College of Pharmacy, Sonepat, Haryana, India, Email: nehabajwa2765@gmail.com

\section{INTRODUCTION}

Herbalism has evolved independently in therapeutic world. The thirst of finding new star in the herbarium solar system is still going on. Now researchers have gone through the plants that feed on human flesh and blood ${ }^{1}$. Botanical Carnivorous plants survive nutrient poor habitat which trap and utilize tiny animals. They do not even bear true roots instead leaves are modified to accommodate a trap function on either aerial or underground/submersed parts. Animals are caught by traps formed by highly specialized metamorphous leaves ${ }^{2}$. Root porosity and root depth were quantified in eight carnivorous plant species and 48 non-carnivorous species within a nutrient-poor wet pine savanna in south Mississippi, USA ${ }^{3}$. Carnivorous and non-carnivorous plant species were contrasted with respect to their indication of wetlands, open habitats, and habitats with nutrient-poor soil that is Carnivorous plants have adapted to grow in places where the soil is thin or poor in nutrients, especially nitrogen, such as acidic bogs and rock outcroppings ${ }^{4}$. In 1860 Charles Darwin found how insects were caught by plants and in 1875 he wrote Insectivorous Plants ${ }^{5}$, the first well-known treatise on carnivorous plants. No carnivorous plant is able to capture prey by its flower. Givnish et al. (1984) proposed that a plant must fulfil two basic requirements to be considered as carnivorous ${ }^{6}$. First, it must be able to absorb nutrients from dead prey, and thereby obtain some increment to fitness in terms of increased growth, pollen production or seed set. Secondly, the plant must have some adaptation or resource allocation whose primary result is the active attraction, capture and/or digestion of prey. Many plants can passively profit by absorbing some nutrients from dead animals decomposing in the soil or on leaf surfaces 7,9. A plant must have at least one adaptation (i.e. active attraction, capture and digestion) in combination with nutrient absorption to be qualified as carnivorous, because many genera of carnivorous plants lack some of these attributes. Likewise, Drosera magnifica is the carnivorous plant that belongs to the largest carnivorous genus Drosera. The plant was discovered and 
authenticated by the botanists Paulo Minatel Gonella, Fernando Rivadavia \& Andreas Fleischmann and subsequently the plant was reported in the Phytotaxa journal $^{7}$.

\section{Evolution:}

Carnivore evolved as a method to increase nutrients in extremely nutrient poor conditions, leading to a costbenefit model for botanical carnivory. ${ }^{8,12}$ Cost-benefit models are given under the assumption that there is a set amount of energy potentially available for an organism, which leads to trade-offs when energy is allocated to certain functions to maximize competitive ability and fitness ${ }^{10,24,30}$. Most carnivorous plants live in habitats with high light, waterlogged soils, and extremely low soil nitrogen and phosphorus, producing the ecological impetus to derive nitrogen from an alternate source. High light environments allowed tradeoff between photosynthetic leaves and prey capturing traps that are photosynthetically inefficient. To compensate for photosynthetically inefficient material, the nutrients obtained through carnivory would need to increase photosynthesis by investing in more leaf mass ${ }^{11,13,15}$. This means when there is a shortage of nutrients and enough light and water, prey capture and digestion has the greatest impact on photosynthetic gains, favoring the evolution of plant adaptations which allowed for more effective and efficient carnivory ${ }^{14,20,26 \& 28}$. Due to the large amount of energy and resources allocated to carnivorous adaptations. i.e. the production of lures, digestive enzymes, modified leaf structures, and the decreased rate of photosynthesis over total leaf area, some authors argue that carnivory is an evolutionary last resort when nitrogen and phosphorus are limited in an ecosystem. All trap types are modifications of a similar basic structure-the hairy leaf ${ }^{16,}{ }^{17,18}$. Hairy (or more specifically, stalked-glandular) leaves can catch and retain drops of rainwater, especially if shield-shaped or peltate, thus promoting bacteria growth. The active glue traps use rapid plant movements to trap their prey. Rapid plant movement can result from actual growth or from rapid changes in cell turgor, which allows cells to expand or contract by quickly altering their water content. Slow-moving flypapers like Pinguicula exploit growth, while the Venus flytrap uses such rapid turgor changes which make glue unnecessary. The stalked glands that once made glue became teeth and trigger hairs in Drosera - an example of natural selection hijacking preexisting structures for new functions ${ }^{19,22 \& 24}$.

\section{Trapping mechanism of Carnivorous plants:}

Five basic trapping mechanisms are found in carnivorous plants ${ }^{21,27,29 \& 30}$.

1. Pitfall traps (pitcher plants) trap prey in a rolled leaf that contains a pool of digestive enzymes or bacteria.

2. Flypaper traps use sticky mucilage.
3. Snap traps utilize rapid leaf movements.

4. Bladder traps suck in prey with a bladder that generates an internal vacuum.

5. Lobster-pots, also known as eel traps, force prey to move towards a digestive organ with inwardpointing hairs.

These traps may be active or passive, depending on whether movement aids the capture of prey. For example, Triphyophyllum is a passive flypaper that secretes mucilage, but whose leaves do not grow or move in response to prey capture ${ }^{23,28}$.

\section{Physiology of carnivorous activity of Drosera:}

Leaves have club shaped hair on their upper surface called tentacles. Tentacles have expanded reddish tips which secrete sticky, purple colored juice which sparkle in the sun like dew drops which helps to attract the insects to the shiny drop. This is the only reason why this plant is called as sun dew. When an insect comes in the contact with the leaf tentacle, the leaf starts secreting as the tentacle is sensitive to the protein body and the insect get trapped in the sticky fluid and the tentacle starts bending. The process is supported by bending and folding of leaf margins to form cup-like structure. Entrapped insects are digested by fluid which contains the protease enzyme that breaks the insect body proteins into to amino acids. These amino acids are absorbed and consumed by the plants for the synthesis of proteins. $^{10,27,29}$ Recently a very interesting and new kind of interaction between insects and carnivorous plants has been reported from Brazil. Larvae of the predatory flower fly Toxomerus basalis have been found scavenging on the sticky leaves of several carnivorous sundew species. This hoverfly apparently spends its larval stage feeding on prey trapped by Drosera leaves ${ }^{30}$.

\section{Classification of carnivorous plants:}

The classification of all flowering plants is currently in a state of flux. In the Cronquist system, the Droseraceae and Nepenthaceae were placed in the order Nepenthales, based on the radial symmetry of their flowers and their possession of insect traps. The Sarraceniaceae was placed either in the Nepenthales, or in its own order, the Sarraceniales. The Byblidaceae, Cephalotaceae, and Roridulaceae were placed in the Saxifragales; and the Lentibulariaceae in the Scrophulariales (now subsumed into the Lamiales) ${ }^{31,32,47}$.

In more modern classification, such as that of the Angiosperm Phylogeny Group, the families have been retained, but they have been redistributed amongst several disparate orders ${ }^{29}$. The family Droseraceae is usually supposed to contain four genera, Drosophyllum, Dionaea, Aldrovanda and Drosera, of which the first three are mono- typic and the fourth, Drosera, has about 125 species $33,34,35$. The current recommendations is shown in Table:1(only carnivorous genera are listed): 
Table 1: Classification of Carnivorous genera

\begin{tabular}{|c|c|}
\hline Dicots & Monocots \\
\hline 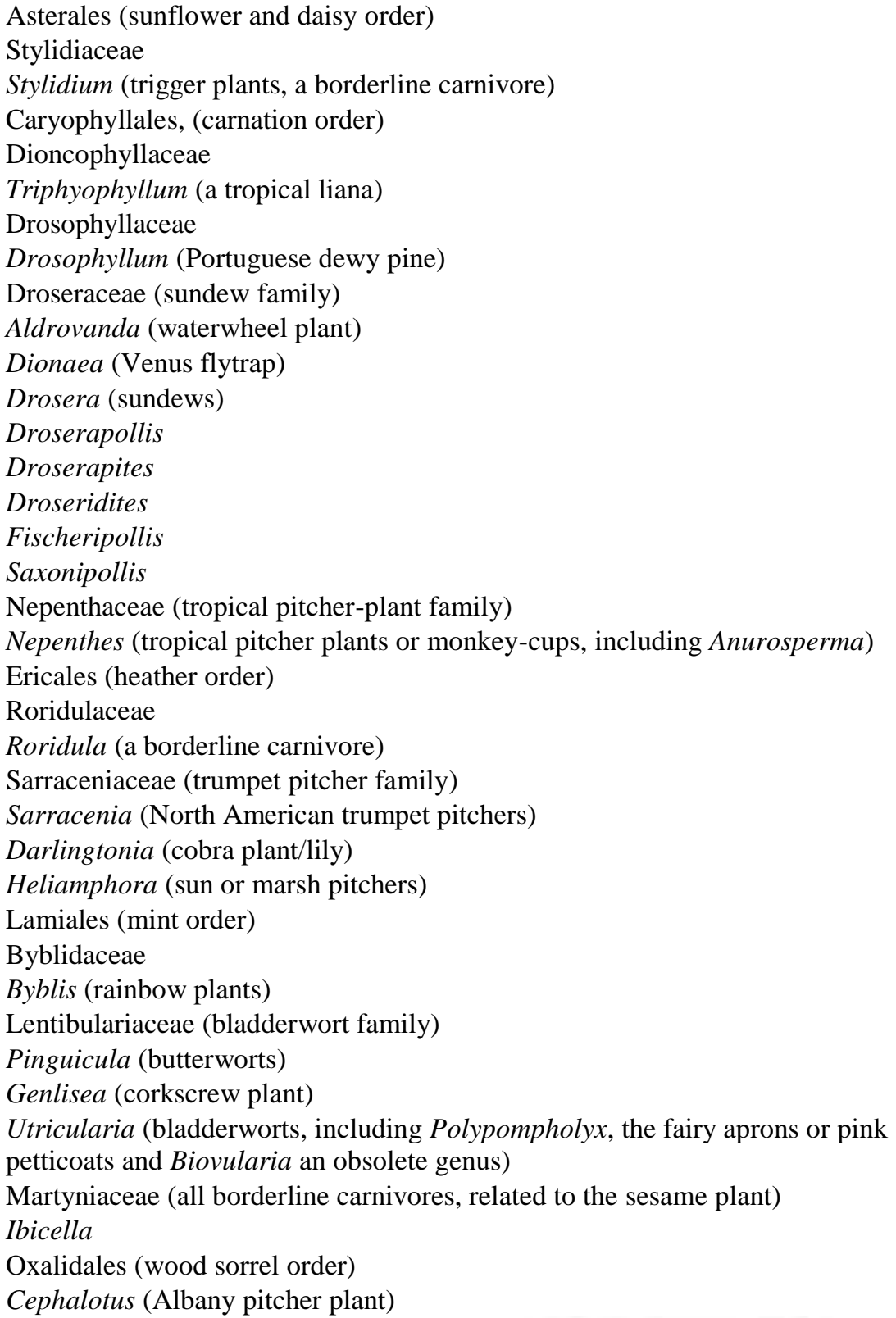 & $\begin{array}{l}\text { Poales (grass order) } \\
\text { Bromeliaceae (bromeliad or pineapple } \\
\text { family) } \\
\text { Brocchinia (a terrestrial bromeliad) } \\
\text { Catopsis (a borderline carnivore) } \\
\text { Eriocaulaceae (pipewort family) } \\
\text { Paepalanthus bromelioides } \\
\text { (a borderline carnivore) }\end{array}$ \\
\hline
\end{tabular}

\section{Droseraceae (Sundew family):}

Charles Darwin, who discovered the carnivorous nature of other Drosera species, wrote: "At this present moment I care more about Drosera than the origin of all the species in the world". Droseraceae is a small family of mostly herbaceous plants, all remarkable for the glandular hair with which they catch insects. These insectivorous herbs secrete enzymes to digest the tissues of insects and often lack chlorophyll ${ }^{25,35}$. The main chemical constituents present in Droseraceae are flavonoids, quinines and other constituents such as carotenoids, resins, tannins, ascorbic acid ${ }^{47,58}$.

\section{Drosera magnifica:}

Scientist Paulo Gonella made a brilliant discovery while scrolling through Facebook. Drosera magnifica is considered as the first new plant species "discovered" on the social network. A botanist Reginaldo Vasconcelos posted a photo of the plant in 2012 while trekking near his home in southeastern Brazil. After a year, Gonella confound across the photograph when another friend of his reposted it on Facebook. Gonella, a plant researcher at the Institute of Biosciences at the University of São Paulo noticed this species of Drosera was new. The plant in the photo seemed totally dissimilar from all the other species, Gonella told Smithsonian.com via Facebook Messenger. Soon, Gonella and Vasconcelos went back to the mountain and confirmed that the plant, Drosera magnifica, was in fact new discovery in the field of science, figure: 1 , represents image of the plant. After examining the plant along with other researchers at the Botanical State Collection in Munich, they declared its discovery in the journal Phytotaxa. ${ }^{36}$ 
It is a species of sundew, endemic to Pico Padre Ângelo (1500-1530 m asl) in eastern Minas Gerais in southeastern Brazil, where it grows among sandstone outcrops in herbaceous and shrubby vegetation. It is one of the three largest species of Drosera - the other two being $D$. regia from South Africa and $D$. gigantea from
Australia $^{36,37,39}$. It is the largest New World sundew, and it is closely related to Drosera graminifolia and Drosera spiralis $^{40,41}$. The genus Drosera presents a worldwide distribution with about 250 species and is currently considered the largest carnivorous plant genus ${ }^{7}$.

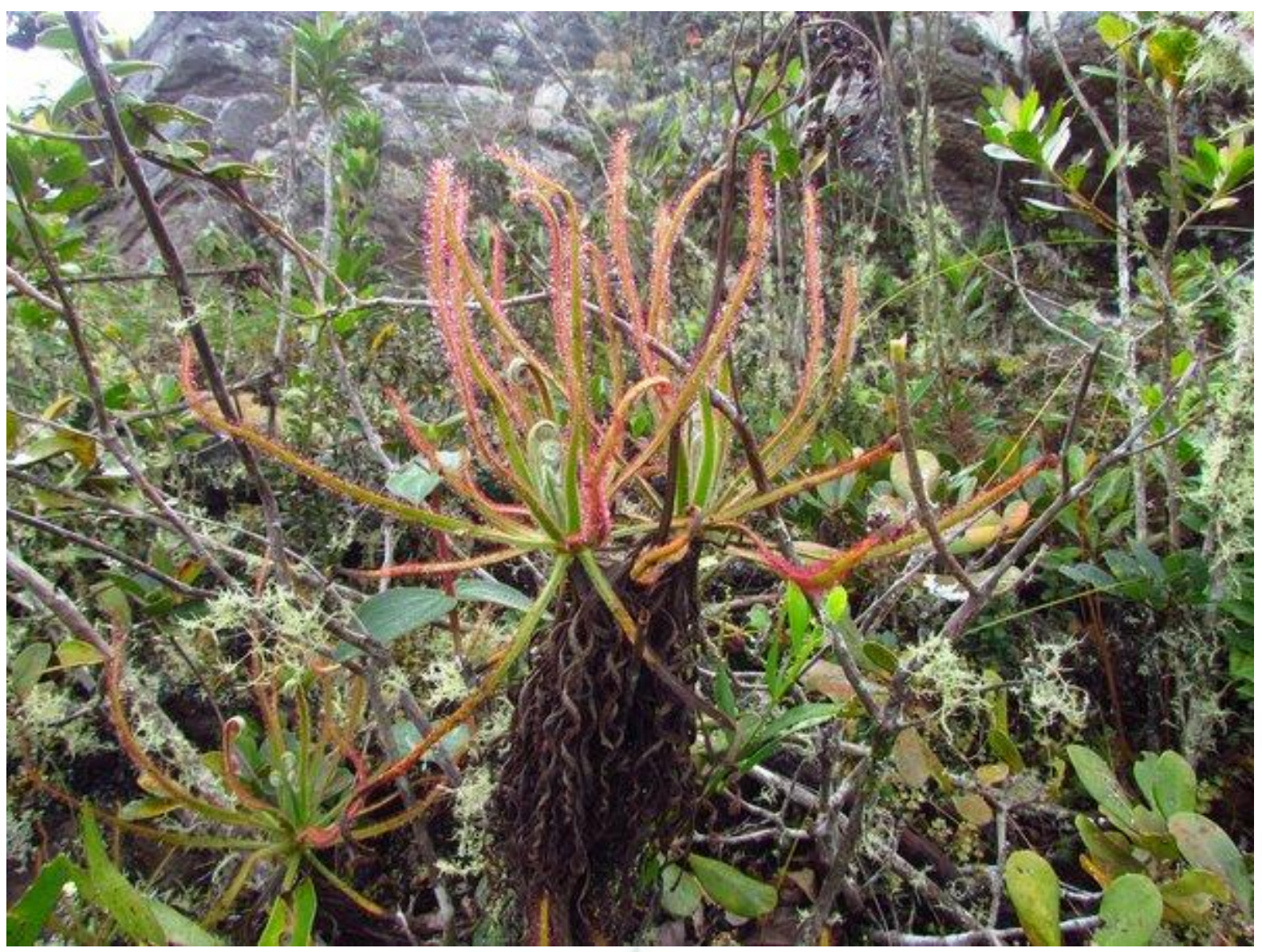

Figure 1: Photograph of Drosera magnifica. Photograph was downloaded from Google images and was confirmed from the site www.smithsonian.com, the source of the photograph.

Paul A. Egan 2013, have discussed in his review article about producing lead compounds from the Drosera to treat tuberculosis and potential role of anthocyanins in nitrogen transport ${ }^{42}$. This article relates Drosera magnifica with other closely related species so that Drosera magnifica can be utilized properly for its potential medicinal activites ${ }^{43-45}$. 8-hydroxy-luteolin-8O-arabinopyranoside, tricetin-7-O-xylopyranoside and 8-hydroxytricetin-8-O-arabinopyranoside were the constituents that were described for the first time using LC-DAD-MS, LC-NMR, and offline 1D and 2D NMR analyses and around 40 different ambiguous substances were also identified ${ }^{46}$. Closely related species to Drosera magnifica are rich in flavonoids, quinines, naphthoquinones and other constituents such as carotenoids, resin, tannins, ascorbic acid etc ${ }^{47-55}$. If screened systematically we cannot rule out the presence of common chemical constituents in Drosera magnifica.

Table 2: Represents the common chemical constituents that are found in the related species of Drosera magnifica.

\begin{tabular}{|l|l|}
\hline Flavonoids & Kaempferol, myricetin, quercetin, hyperoside etc \\
\hline Quinines & Plumbagin, hydroplumbagin glucoside, $7-$ methyljuglone $^{58,59}$. \\
\hline Tannins / Resins & Tannins (Ellagic acid) and resins are also present in Drosera \\
\hline Plant acids & Butyric acid, citric acid, formic acid, gallic acid, malic acid \\
\hline Ascorbic Acid & Vitamin $\mathrm{C}^{60,61}$. \\
\hline Carotenoids & Carotenoid $\mathrm{a}+\mathrm{b}^{57}$. \\
\hline
\end{tabular}


Based on the chemical constituents, there are some common pharmacological properties of species related to Drosera magnifica:

1) Antioxidant activity:

Due to the presence of good amount of flavonoids and quinines the plant would possess high antioxidant activity $^{62}$.

2) Inflammation:

As Drosera rotundifolia possesses good antiinflammatory activity due to the presence of flavonoids. Drosera magnifica is also prone to possess antiinflammatory mechanisms via their ability to inhibit reactive oxygen or nitrogen compounds ${ }^{63-67}$.

3) Cancer:

Dietary flavonoid intake is associated with reduced gastric carcinoma risk in women, and reduced aero digestive tract cancer risk in smokers. So there may be chances that Drosera magnifica can be used to reduce carcinoma risk due to presence of both quinines and flavonoids ${ }^{67-71}$.

4) Cardiovascular disease:

Flavonoids have the property to treat cardiovascular diseases, so the presence of good amount of flavonoids in Drosera genus hints that Drosera magnifica may have the following actions ${ }^{71-77}$ :

- inhibit coagulation, thrombus formation or platelet aggregation

- reduce risk of atherosclerosis

- reduce arterial blood pressure and risk of hypertension

- reduce oxidative stress and related signaling pathways in blood vessel cells

- modify vascular inflammatory mechanisms

- improve endothelial and capillary function

- $\quad$ modify blood lipid levels

- regulate carbohydrate and glucose metabolism

- modify mechanisms of aging

5) Antimicrobial Activity:

Drosera magnifica may also have direct antibacterial activity, synergistic activity with antibiotics, and the ability to suppress bacterial virulence factors in numerous in vitro and a limited number of in vivo studies due to presence of flavonoids and Quinones ${ }^{77.78 .79}$.

\section{6) Biochemistry:}

Derivatives of quinones are common in biologically active molecules as an electron acceptor as well as for production of useful metabolites in aerobic respiration. Hence Drosera magnifica may be used for production of various metabolites in biochemistry ${ }^{80-83}$.

7) Dying Agent:
Due to presence of quinines Drosera magnifica may be used as natural dyes ${ }^{84}$.

8) Antispasmodic effects:

D. Madagascariensis having flavonoid is said to affect the $\mathrm{M}_{3}$ muscarinic receptors in smooth muscle, causing the antispasmodic effects so D. magnifica is prone to show antispasmodic activity as well ${ }^{85-90}$.

9) Antiangiogenic effects

Ellagic acid present in D. rotundifolia possess antiangiogenic activity so D. magnifica may be properly utilized for the screening of antiangiogenic activity ${ }^{91}$.

10) Nanotechnology:

The mucilage produced by Drosera has remarkable elastic properties and has made this genus a very attractive subject in biomaterials research. In one recent study, the adhesive mucilage of three species $D$. binata, $D$. capnesis and D. spatulata were analyzed for nano fiber and nanoparticle content ${ }^{92,93,94}$. So D. magnifica, if utilized properly can lead its way in novel drug delivery aspects.

11) Miscellaneous uses:

D. rotundifolia, D. anglica and D.linearis as being used as stimulants and expectorants, hence $D$. magnifica may be used for treating bronchitis, whooping cough, and tuberculosis ${ }^{95}$. Also due to the presence of tannins/ resins D.magnifica may be used for varnishes, adhesives, colouring, as well as various therapeutic activities.

\section{DISCUSSIONS}

As there is no systematic literature available of this newly discovered plant our article will provide directions to the scientists based on the scientific rationale so that the plant should be properly utilized in the field of medicine. IUCN has mentioned Drosera magnifica as critically endangered species so it is our duty to study this plant more carefully in regard to conserving its habitat and proper utilization. Species of carnivorous genus Drosera have long been used as a source of potent products. We didn't have substantial literature of Drosera magnifica, in treating various diseases so this article provides a bridge between Drosera magnifica to the various other closely related species. Rich constituents like flavonoids, quinines, naphthoquinones, resin, tannins are widely found in the genus Drosera that have potent medicinal values and there is high probability of finding these constituents in Drosera magnifica as well according to the literature we surveyed.

\section{CONCLUSION}

The present study gives a mind opening view on Drosera magnifica that how this plant can be utilized in treating health ailments based on the probability of the various chemical constituents that may be present in it. It gives the scientists a chassis as well as direction to research this newly discovered plant for its pharmacological activities so that the plant can make its 
way into the pharmaceutical industry in a much more constructive way.

\section{Summary:}

- Drosera magnifica a new species of Droseraceae family.

- D. magnifica may be rich in flavonoids, quinines and other constituents such as carotenoids, resin, tannins, ascorbic acid.

- D. magnifica may be having anti-inflammatory, antispasmodic, antibacterial, anti-tumor activity.

\section{REFERENCES}

1. Berg, C. van den Reaching a compromise between conflicting nuclear and plastid phylogenetic trees: a new classification for the genus Cattleya (Epidendreae; Epidendroideae; Orchidaceae). Phytotaxa 2014; 186(2):75-86

2. Gonella, P.M., Rivadavia, F., Sano, P.T. \& Fleischmann, A. Exhuming Saint-Hilaire: revision of the Drosera villosa complex (Droseraceae) supports 200 year-old neglected species concepts. Phytotaxa. 2014; 156(1):1-40.

3. Leme, E.M.C \& Kollmann, L. (Miscellaneous new species of Brazilian Bromeliaceae. Phytotaxa 2013; 108(1):1-40

4. Leme, E.M.C., Till, W., Kollmann, L.J.C., de Moura, R.L. \& Ribeiro, O.B.C. Miscellaneous new species of Brazilian Bromeliaceae- III. Phytotaxa (2014) 177 (2): 61-100.

5. Rivadavia, F. Four new species of sundews, Drosera (Droseraceae), from Brazil. Carnivorous Plant Newsletter. 2003; 32(3):79-92.

6. Stephens, E.L. A new sundew, Drosera regia (Stephens), from the Cape Province. Transactions of the Royal Society of South Africa. 1926; 8:309-313

7. Gonella P., Rivadavia F. \& Fleischmann A. Drosera magnifica (Droseraceae): the largest New World sundew, discovered on Facebook, Phytotaxa 2015; 220(3):257-267

8. Krenn, L., Blaeser, U., Hausknost-Chenicek, N. Determination of naphthoquinones in Droserae herba by reversedphase high performance liquid chromatography. $J$. Liqu. Chrom. \& Rel. Technol. 1998; 21:3149-3160,

9. Aboussouan, L.S.: Acute exacerbations of chronic bronchitis focusing management for optimum results. Postgrad. Med. 1996; 99:89-102,

10. Arakida, Y., Suwa, K., Ohga, K., Yokota, M., Miyata, K., Yamada, T. \& Honda, K.: In vitro pharmacologic profile of YM158, a new dual antagonist for LTD4 and TXA2 receptors J. Pharmacol. Exp. Ther. 1998; 287:633-639,

11. Barnes, P.J.: Muscarinic receptor subtype in airways. Life Sci. 1993; 52:521-527.

12. Barnes, P.J.: Neuroeffector mechanisms: the interface between inflammation and neuronal responses. J. Allergy Clin. Immunol. 1996; 98:73-81.

13. Busse, W.W., Kopp, D.E., Middleton, E. Jr.: Flavonoid modulation of human neutrophil function. J. Allergy Clin. Immunol. 1984; 73:801-809

14. Czygan, F.-C., Wichtl, M.: Droserae Herba. In: Teedrogen und Phytopharmaka, 3rd ed., M. Wichtl, ed., Wissenschaftliche Verlagsgesellschaft mbH, Stuttgart, 1997; 188-190.

15. Didry, N., Dubreuil, L., Trotin, F., Pinkas, M.: Antimicrobial activioty of the aerial parts of Drosera peltata Smith on oral bacteria. J. Ethnopharmacol. 1998; 60:91-96.

16. Kawabata, K., Hagio, T., Matsumoto, S., Nakao, S., Orita, S., Aze, Y., Ohno, H.: Delayed neutrophil elastase inhibition prevents subsequent progression of acute lung injury induced by endotoxin inhalation in hamsters. Am. J. Respir. Crit. Care Med. 161:2013-2018.

17. Kirsch, C.: Problematik bei der Beschaffung von DroseraDroge. Workshop "Herba Droserae - Botanik, Inhaltsstoffe, Analytik", Vienna 1995, 10. 11
- Future research can be done to find these activities of $D$. magnifica and utilize the plant in a more effective way.

Acknowledgment: The authors are thankful to Dr.Gajendra Singh, Principal, College of Pharmacy, (P.G.I.M.S), Rohtak for providing the support to write this review.

Conflict of Interest: There is no conflict of interest

18. Krahl, R.: Ein wirksames Prinzip aus Drosera rotundifolia. Arzneimittelforschung 1995; 6:342-348.

19. Krenn, L., Länger, R., Kopp, B.: Qualitätsprüfung von Sonnentaukraut. Deutsche Apothekerzeitung 135: 867-870.

20. Krenn, L., Blaeser, U., Hausknost-Chenicek, N.: Determination of naphthoquinones in Droserae herba by reversed phase high performance liquid chromatography. $J$. Liqu. Chrom. \& Rel. Technol. 1998; 21:3149-3160.

21. Krenn, L., Digruber, B., Wawrosch Ch.: Der Einfluss von Trocknung und Lagerung auf den Naphthochinongehalt von Hb. Droserae. Z. Arzn. Gew.pfl. 1998; 3:162-165.

22. Krenn, L., Danzer, V., Tongiani, S.: HPLC-separation and quantitative determination of flavonoids in Sundew herb. In: Polyphenol Communications 2000; 173-174.

23. Lozoya X., Meckes, M., Abou-Zaid, M., Tortoriello, J., Nozzolillo, C., Arnason, J.T.: Quercetin glycosides in Psidium guajava L. leaves and determination of a spasmolytic principle. Arch. Med. Res. 1994; 25:11-15.

24. Pertz, H., Elz, S.: In-vitro pharmacology of sarpogrelate and the enantiomers of its major metabolite: 5-HT2A receptor specificity, stereoselectivity and modulation of ritanserininduced depression of 5-HT contractions in rat tail artery. J. Pharm. Pharmacol. 1994; 47:310-316.

25. Schilcher, H.: Drosera - der Sonnentau: ein bewährtes Antitussivum. Zeitschrift f. Phytotherapie 1993, 14: 50-54.

26. Angiosperm Phylogeny Group An update of the Angiosperm Phylogeny Group classification for the orders and families of flowering plants: APG III.Bot. J. Linn. Soc.2009; 161:105121

27. Brittnacher, J., 2011. Drosera _ hybrida rest in peace. Carniv. Plant Newslett. 40, 112e121.Chase, M.W., Reveal, J.L. A phylogenetic classification of the land plants to accompany APG III. Bot. J. Linn. Soc. 2009; 161:122-127.

28. Culham, A., Gornall, R.J. The taxonomic significance of naphthoquinones in the Droseraceae. Biochem. Syst. Ecol. 1994; 22:507-515.

29. Durand, R., Zenk, M.H., 1974. The homogentisate ringcleavage pathway in the biosynthesis of acetate-derived naphthoquinones of the Droseraceae. Phytochem.1974; 13:1483-1492.

30. Andreas, F., Fernando, R., Paulo,M.G., Celeste, P.B.,Ximo,M., Santos,R. Where Is My Food? Brazilian Flower Fly Steals Prey from Carnivorous Sundews in a Newly Discovered PlantAnimal Interaction. Plos One. 2016, 11, 1-15.

31. Egan, P.A., van der Kooy, F. Coproduction and ecological significance of naphthoquinones in carnivorous sundews (Drosera). Chem. Biodivers. 2012; 9:1033-1044.

32. Hegnauer, R. Plumbaginaceae. In: Chemotaxonomie der Pflanzen 5. Birkh€auser, Basel, 1969, pp. 341-347.

33. Hegnauer, R. Ancistrocladaceae, Dioncophyllaceae, Droseraceae, Ebenaceae. In: Chemotaxonomie der Pflanzen 8. Birkh€auser, Basel, 1989; 39-41, 388-389,399-401, 402-411.

34. Hegnauer, R., Nepenthaceae, Plumbaginaceae. In: Chemotaxonomie der Pflanzen 9. Birkh€auser, Basel, 1990, pp. 132-133, 255-258. 
35. Kaelin, M., 2014. The sundew hybrid Drosera _ beleziana found on Long Island, New York. Carniv. Plant Newslett. 2014; 43:97-99.

36. Macfarlane, J.M., 1899. Observations on some hybrids between Drosera filiformis and D. intermedia. Trans. Proc. Bot. Soc. Pa 1899, 1, 87-99.

37. Marabini, J., 2014. Ein seltener Vertreter der Familie Droseraceae im Sebalder Reichswald: Drosera _ beleziana Camus (Drosera rotundifolia L. _ Drosera intermedia Hayne). RegnitzFlora 2014; 6:59-61.

38. Meimberg, H., Dittrich, P., Bringmann, G., Schlauer, J., Heubl, G. Molecular phylogeny of Caryophyllidae s. 1. based on matK sequences with special emphasis on carnivorous taxa. Plant Biol. 2000; 2:218-228.

39. Pearman, D.A., Rumsey, F.J. Drosera _ belezeana camus confirmed for the British Isles. Watsonia 2004; 25:115- 119.

40. Schlauer, J. 'New' data relating to the evolution and phylogeny of some carnivorous plant families. Carniv. Plant Newslett. 1997; 26:34-38.

41. Schlauer, J., Nerz, J., Rischer, H. Carnivorous plant chemistry. Acta Bot. Gallica 2005; 152:187-195.

42. Paul, A.E., Frank, V.D.K. Phytochemistry of the Carnivorous Sundew Genus Drosera (Droseraceae)- Future Perspectives and Ethnopharmacological Relevance. Chemistry \& Biodiversity 2013; 10:1774-1790.

43. Budzianowski, J., Skrzypczak, L., Kukulczanka, K. Phenolic compounds of Drosera intermedia and D. spathulata from in vitro cultures. Acta Hortic. 1993; 330:277-280.

44. Conran, J.G., Gunta Jaudzems, V., Hallam, N.D. Droseraceae germination pattern and their taxonomic significance. Bot. J. Linn. Soc. 1993; 123:211-223.

45. Culham, A., Gornall, R.J. The taxonomic significance of naphthoquinones in the Droseraceae. Biochem. Syst. Ecol.1994; 22:507-515.

46. Braunberger, C., Zehl, M., Conrad, J., Wawrosch, C., Strohbach, J., Beifuss, U., Krenn, L. Flavonoids as chemotaxonomic markers in the genus Drosera. Phytochemistry. 2015; 118:74-82.

47. Faiella, L., Temraz, A., De Tommasi, N., Braca, A. Diterpenes, ionol-derived, and flavone glycosides from Podocarpus elongates. Phytochemistry 2012; 76:172-177.

48. Fico, G., Braca, A., Bilia, A.R., Tome, F., Morelli, I. Flavonol glycosides from the flowers of Aconitum paniculatum. J. Nat. Prod. 2000; 63:1563-1565.

49. Fukushima, K., Nagai, K., Hoshi, Y., Masumoto, S., Mikami, I., Takahashi, Y., Kobori, M. Drosera rotundifolia and Drosera tokaiensis suppress the activation of HMC-1 human mast cells. J. Ethnopharmacol. 2009; 125:90-96.

50. Jhoo, J.W., Sang, S., He, K., Cheng, X., Zhu, N., Stark, R.E., Zheng, Q.Y., Rosen, R.T., Ho, C.T. Characterization of the triterpene saponins of the roots and rhizomes of blue cohosh (Caulophyllum thalictroides). J. Agric. Food Chem. 2001; 49:5969-5974.

51. Kolodziej, H., Pertz, H.H., Humke, A. Main constituents of a commercial Drosera fluid extract and their antagonist activity at muscarinic M3 receptors in guinea-pig ileum. Pharmazie 2002; 57:201-203.

52. Kovác`ik, J., Klejdus, B., Štork, F., Hedbavny, J. Prey-induced changes in the accumulation of amino acids and phenolic metabolites in the leaves of Drosera capensis L. Amino Acids 2012; 42:1277-1285.

53. Krenn, L., Kartnig, T., 2005. Sonnentau - Aktuelles über medizinisch genutzte Drosera-Arten. Z. Phytother. 2005; 26:197-202.

54. Krenn, L., Blaeser, U., Hausknost-Chenicek, N. Determination of naphthoquinones in Droserae herba by reversed-phase high performance liquid chromatography. J. Liq. Chromatogr. Relat. Technol. 1998; 21:3149-3160.

55. Krenn, L., Beyer, G., Pertz, H.H., Karall, E., Kremser, M., Galambosi, B., Melzig, M.F. In vitro anti-spasmodic and antiinflammatory effects of Drosera rotundifolia. Arzneimittelforschung/Drug Res. 2014; 54:402-405.

56. Krolicka, A., Szpitter, A., Gilgenast, E., Romanik, G., Kaminski, M., Lojkowska, E. Stimulation of antibacterial naphthoquinones and flavonoids accumulation in carnivorous plants grown in vitro by addition of elicitors. Enzyme Microb. Technol.2008; 42:216-221.

57. Krolicka, A., Szpitter, A., Maciag, M., Biskup, E., Gilgenast, E., Romanik, G., Kaminski, M., Wegrzyn, G., Lojkowska, E. Antibacterial and antioxidant activity of the secondary metabolites from in vitro cultures of the Alice sundew (Drosera aliciae). Biotechnol. Appl. Biochem. 2009; 53:175184.

58. Länger, R., Kopp, B. Qualitätsprüfung von Sonnenkraut. 1. Grundlagen für die botanische Identitätsprüfung. Dtsch. Apoth. Ztg. 1995; 135:657-664.

59. Marchant, N.G., Ashton, H.I., George, A.S., 1982. Drosera. In: George, A.S. (Ed.), Flora of Australia, Lecythidales to Batales, vol. 8. Australian Government Printing Service, Canberra, Australia, pp. 9-66.

60. Marczak, Ł., Kawiak, A., Łojkowska, E., Stobiecki, M. Secondary metabolites in in vitro cultured plants of the genus Drosera. Phytochem. Anal. 2005; 16:143-149.

61. Melzig, M.F., Pertz, H.H., Krenn, L.Anti-inflammatory and spasmolytic activity of extracts from Droserae herba. Phytomedicine 2001; 8:225-229.

62. Murashige, T., Skoog, F. A revised medium for rapid growth and bio assays with tobacco tissue cultures. Physiol. Plant.1962; 15:473-497.

63. D.H., Karall, E., Kremser, M., Krenn, L. Comparison of the antiinflammatory effects of Drosera rotundifolia and Drosera madagascariensis in the HET-CAM assay. Phytother. Res. 2005; 19:323-326.

64. Planchon, J.E., 1848. Sur la famille des Droséracées. Ann. Sci. Nat. Bot. 1848, 3, 79-98, 185-207, 285-309.

65. Rivadavia, F., Kondo, K., Kato, M., Hasebe, M. Phylogeny of the sundews, Drosera (Droseraceae), based on chloroplast rbcL and nuclear $18 \mathrm{~S}$ ribosomal DNA sequences. Am. J. Bot. 2003; 90:123-130

66. Rouis, Z., Abid, N., Aouni, M., Faiella, L., Dal Piaz, F., De Tommasi, N., Braca, A. Benzophenone glycosides from Hypericum humifusum ssp. austral. J. Nat. Prod. 2013; 76:979-982.

67. Schlauer, J. A dichotomous key to the genus Drosera L. (Droseraceae). Carniv. Plant Newslett. 1996; 25:67-88.

68. Seine, R., Barthlott, W. Some proposals on the infrageneric classification of Drosera L. Taxon 1994; 43:583-589.

69. Wang, Q., Su, J., Zeng, L. The isolation and identification of flavonoids from Drosera burmannii. Zhong Yao Cai 1998; 21:401-403.

70. Watanabe, M. Antioxidative phenolic compounds from Japanese barnyard millet (Echinochloa utilis) grains. J. Agric. Food Chem. 1999; 47:4500-4505.

71. Yang Kuo, L.M., Zhang, L.J., Huang, H.T., Lin, Z.H., Liaw, C.C., Cheng, H.L., Lee, K.H., Morris-Natschke, S.L., Kuo, Y.H., Ho, H.O. Antioxidant lignans and chromone glycosides from Eurya japonica. J. Nat. Prod. 2013; 76:580-587.

72. Zehl, M., Braunberger, C., Conrad, J., Crnogorac, M., Krasteva, S., Vogler, B., Beifuss, U., Kenn, L.Identification and quantification of flavonoids and ellagic acid derivatives in therapeutically important Drosera species by LC-DAD, LCNMR, and LC-MS. Anal. Bioanal. Chem. 2011; 400:25652576 .

73. Zenk, M.H., Fürbringer, M., Steglich, W. Occurrence and distribution of 7-1methyljuglone and plumbagin in the Droseraceae. Phytochemistry 1969; 8:2199-2200

74. Lowrie, Allen: A taxonomic revision of Drosera section Stolonifera (Droseraceae) from south-west Western Australia, Nuytsia 2005; 15(3):355-393

75. Rivadavia, Fernando; Kondo, Katsuhiko; Kato, Masahiro und Hasebe, Mitsuyasu: Phylogeny of the sundews, Drosera (Droseraceae), based on chloroplast rbcL and nuclear $18 S$ ribosomal DNA Sequences, American Journal of Botany. 2003; 90:123-130.

76. Adamec, L. Mineral nutrition of carnivorous plants: a review. Bot. Rev. 1997; 63:273-299.

77. Adamec, L., Kohout, P., Benes, K. Root anatomy of three carnivorous plant species. Carniv. Plant Newslett. 2006; $35: 19-22$. 
78. Albert, V.A., Williams, S.E., Chase, M.W. Carnivorous plants: phylogeny and structural evolution. Science 1992; 257:14911495.

79. Armstrong, W.Are-examination of the functional significance of aerenchyma. Physiol. P1ant. 1972; 27:173-177.

80. Both, G.J., Gerards, S., Laanbroek, H.J. The occurrence of chemo-autotrophic nitrifiers in water-saturated grassland soils. FEMS Microbiol. Ecol. 1992; 23:15-26.

81. Brewer, J.S. Patterns of plant species richness in a wet slash pine (Pinus elliottii) savanna. J. Torrey Bot. Soc. 1998; 125:216-224.

82. Brewer, J.S. Short term effects of fire and competition on growth and plasticity of Sarracenia alata (Sarraceniaceae). Am. J. Bot. 1999; 86:1264-1271.

83. Brewer, J.S. Why don't carnivorous pitcher plants compete with noncarnivorous plants for nutrients? Ecology 2003; 84:451-462.

84. Brewer, J.S., Menzel, T. A method for evaluating outcomes of restoration when no reference sites exist. Restor. Ecol.2009; 17:4-11.

85. Brewer, J.S., Cunningham, A.L., Moore, T.P., Brooks, R.M., Waldrup, J.L. A sixyear study of fire-related cues and coexistence of two perennial grasses in a wet longleaf pine (Pinus palustris) savanna. Plant Ecol. 2009; 200:141-154.

86. Burdick, D.M., 1989. Root aerenchyma development in Spartina patens in response to flooding. Am. J. Bot. 1989; 76:777-780
87. Depuy, N.C., Dreyfus, B.L. Bradyrhizobium populations occur in deep soil under the leguminous tree Acacia albida. Appl. Environ. Microbiol. 1992; 58:2415-2419.

88. Dixon, K.W., Pate, J.S. Phenology, morphology, and reproductive biology of the tuberous sundew, Drosera erythrorhiza Lindl. Aust. J. Bot. 1978; 26:441-454.

89. Ellison, A.M. Nutrient limitation and stoichiometry of carnivorous plants. Plant Biol. 2006; 8:740-747.

90. Ellison, A.M., Gotelli, N.J. Evolutionary ecology of carnivorous plants. Tree 2001; 16: 623-629.

91. Ellison, A.M., Gotelli, N.J. Energetics and the evolution of carnivorous plants_-Darwin's "most wonderful plants in the world". Exp. Bot.2009; 60:19-42.

92. Fellows, R.J., Patterson, R.P., Raper Jr., C.D., Harris, D. Nodule activity and allocation of photosynthate of soybean during recovery from water stress. Plant Physiol.1987; $84: 456-460$.

93. Givnish, T.J., 1989. Ecology and evolution of carnivorous plants. In: Abrahamson, W.G. (Ed.), Plant-Animal Interactions. McGraw-Hill, New York, pp. 242-290.

94. Givnish, T.J., Burkhardt, E.L., Happel, R.E., Weintraub, J.D. Carnivory in the bromeliad Brocchinia reducta, with a cost/benefit model for the general restriction of carnivorous plants to sunny moist, nutrient-poor habitats. Am. Nat. 1984; 124:479-497.

95. Hinman, S.E., Brewer, J.S. Responses of two frequentlyburned wet pine savannas to an extended period without fire. J. Torrey Bot. Soc. 2007; 134:512-526. 